Abstracta Iranica Abstracta Iranica

Revue bibliographique pour le domaine irano-aryen

Volume 30 | 2010

Comptes rendus des publications de 2007

\title{
« Al-Farghānī On the Astrolabe ». Boethius, Band 52, Stuttgart, Franz Steiner Verlag, 2005, viii + 447 p.
}

\section{Sonja Brentjes}

\section{(2) OpenEdition}

1 Journals

\section{Édition électronique}

URL : http://journals.openedition.org/abstractairanica/37981

DOI : 10.4000/abstractairanica.37981

ISSN : 1961-960X

Éditeur :

CNRS (UMR 7528 Mondes iraniens et indiens), Éditions de l'IFRI

\section{Édition imprimée}

Date de publication : 8 avril 2010

ISSN : 0240-8910

\section{Référence électronique}

Sonja Brentjes, « «Al-Farghānī On the Astrolabe ». Boethius, Band 52, Stuttgart, Franz Steiner Verlag, 2005, viii + 447 p. », Abstracta Iranica [En ligne], Volume 30 | 2010, document 243, mis en ligne le 08 avril 2010, consulté le 26 septembre 2020. URL : http://journals.openedition.org/abstractairanica/ 37981 ; DOI : https://doi.org/10.4000/abstractairanica.37981

Ce document a été généré automatiquement le 26 septembre 2020.

Tous droits réservés 


\title{
« Al-Farghānī On the Astrolabe ». Boethius, Band 52, Stuttgart, Franz Steiner Verlag, 2005, viii +447 p.
}

\author{
Sonja Brentjes
}

1 Lorch established and translated for the first time into a modern language a work by the well-known astronomer and engineer of the ninth century, Ahmad al-Farghānī, one title of which is The Complete [Work] on the Northern and Southern Astrolabe with Geometrical and Computational Explanations. Al-Farghān's text is the first work known to us by a Muslim author that explains the theory of the astrolabe. It consists of an introduction and seven chapters. In the introduction the author justifies his work. In Chapter 1 he explains the geometrical principles of stereographic projection of the sphere from the south pole onto the plane tangent to its north pole. Chapters 2 and 3 expound computational and geometrical procedures. Chapter 4 contains tables of the quantities the construction and computation of which al-Farghānī explained previously. Chapters 5 and 6 describe how to construct astrolabes for the northern and the southern hemisphere. The final chapter comments on other available projections rejecting them as either unviable or fancy. In addition to establishing and translating the text, Lorch discusses in a commentary the content of al-Farghāni's work and the historical issues posed by it.

\section{INDEX}

Thèmes : 10. Histoire des Sciences et des Techniques 
AUTEURS

SONJA BRENTJES

Universidad de Sevilla - Espagne 